\title{
Shared Responsibility and Reverse Logistics Systems for e-Waste in Brazil
}

\author{
João Ernesto Brasil Migliano \\ miglianojeb@gmail.com \\ CENTRO UNIVERSITÁRIO DA FEI \\ Jacques Demajorovic \\ jacquesd@fei.edu.br \\ CENTRO UNIVERSITÁRIO DA FEI \\ Lucia Helana Xavier \\ lucia.xavier@fundaj.gov.br \\ FUNDAJ
}

A B S TRACT: The National Policy for Solid Waste (NPSW), passed in 2010, established a system of shared responsibility for waste management in Brazil, including Waste of Electrical and Electronic Equipment (WEEE). This law requires the collection and disposal of technological waste through the implementation of Reverse Logistics Systems (RLS). In this study we discuss the main challenges and prospects in implementing WEEE reverse logistics in Brazil. The research was conducted through document analysis and interviews with different players, who are participants in the process of establishing a sector agreement. The findings suggest that the shared responsibility model proposed by the NPSW is not comprehensive enough to deal with the complexity of the Brazilian WEEE reverse chain. Based on this research we were able to propose a broader model covering the interrelationships among all the agents that interfere directly, indirectly, locally and abroad with the implementation of reverse logistics chain practices for electrical and electronic consumer goods in Brazil.

Keywords: Reverse logistics. Shared responsibility. Recycling. Waste picker cooperatives. Socio-environmental risks. 


\section{INTRODUCTION}

The expansion of the Information and Communication Technology (ICT) market is the result of an unprecedented technological development. It was coupled with significant investments in technological innovation and marketing, and improvement in distribution systems, favoring the sales of electronic products in a worldwide scale. At the same time, the large revenues generated by these products were made possible because this system succeeded in promoting rapid obsolescence through the shortening of product life cycle (Kiddee et al., 2013). Widemer et al. (2005) report that, between 1992 and 2005, computers' average lifespan has decreased from 4.5 to 2 years. As a result, there is increasing consumption of non-renewable natural resources and generation of e-waste, which contains toxic substances such as mercury, chromium, cadmium and lead, with significant potential to harm human health and the environment when improperly disposed of. In order to face this challenge, Extended Producer Responsibility (EPR) gained popularity as a public policy in several developed countries, mostly in Europe, and in a few developing countries such as India and China (Gottberg et al., 2006; Milanez \& Bührs, 2009; Manomaivibool, 2009; Xiang \& Ming, 2011). It is expected that, by forcing manufacturers to take back products after usage, managers will increase investments in Design for the Environment (Atasu \& Wassenhove, 2012; Birch et al., 2012), stimulating the use of more recyclable and less toxic materials in electronics components. However, the current scenario for electronic waste management is not very different from the one proposed by Wagner (2009). According to this author, there is no evidence that manufacturers will work towards producing equipment with greater recycling potential while there is an exponential increase in consumption and disposal, and also low rates of technological waste recyclability. These aspects contribute to compromise environmental safety around the world (Li et al., 2013).

On the other hand, reverse logistics, as one of the key elements of the EPR approach, has made remarkable progress in different countries and has become a subject of a growing interest for managers and academics. Legislation and increasing pressure from consumers for corporate social responsibility (Jayaraman \& Lou, 2007) may be perceived as the drivers in this process. As a result, the expansion of Reverse Logistics Systems (RLS) is observed in sev- eral developed countries. On the contrary, in developing countries RLS are still in their preliminary stages (Schluep et al., 2009; Lau \& Wang, 2009).

Schluep et al. (2009), Manomaivibool and Vassanadumrongdee, (2011) and Wang et al. (2012) argue that in those countries initiatives to implement RLS are challenged by the lack of legislation, the low level of public awareness about WEEE environmental impacts, and the existence of informal waste pickers, who are responsible for the expansion of collecting and processing materials, although unprepared to prevent environmental and health impacts. In Brazil, the major step taken to overcome such challenges was the approval of the National Policy for Solid Waste (NPSW) in 2010. According to this law, all the 5,570 Brazilian municipalities must define waste management plans and reverse logistics systems for six main waste categories: (i) batteries; (ii) agrochemical packagings; (iii) used lubricants and lubricant packagings; (iv) tires; (v) lamps and (vi) electrical and electronic equipment waste (WEEE).

Demajorovic and Migliano (2013) highlight as the main merits of the new legislation the recognition of shared responsibility for the product life cycle through sector agreements, which should be agreed upon and signed until 2014, and the inclusion of Reverse Logistics for WEEE. Furthermore, the authors emphasize the legislation's innovative character in encouraging the integration of waste pickers organizations as providers of Reverse Logistics Programs for manufacturers. Even considering such improvements, the authors point out that challenges already mentioned in previous research (Thierry et al., 1995; Braga Junior et al., 2006; Stock and Mulki, 2009) still remain in the current Brazilian scenario.

Most managers still believe that collection, transportation and recycling costs are greater than the economic benefits obtained, which would explain their low interest in exploring potential opportunities in reverse logistics activities (Thierry et al., 1995; Barga Junior et al., 2006; Leite et al., 2009). Recently, some authors have proposed a sustainable approach to reverse logistics, introducing concepts like Closed-loop Supply Chain (Hashemi et al., 2014; Govindan et al., 2014) and Sustainable Supply Chain (Vermeulen \& Kok, 2012; Boukherroub et al., 2014). In this paper we aim to discuss the main challenges and prospects for implementing WEEE reverse logistics in Brazil, from the viewpoint of the 
decision-makers engaged, directly or indirectly, in the segment.

\section{REVERSE LOGISTICS: CHALLENGES AND OPPORTUNITIES}

The NPSW was timely passed, as there has been a significant increase in the Brazilian technological industry, favored by the recent increase in household income (Araújo et al., 2012). Thus, collection of electronic equipment at the end of its life cycle and its proper disposal are essential to prevent the potential environmental impacts caused by the increased generation of this kind of waste. However, as it is a relatively new issue in the country, there is a lack of research focusing on the consequences of the law and the effectiveness in implementing reverse logistics.

Nowadays, logistics issues are usually included in business strategy discussions; important decisions are involved, as shipping and inventory management have become fundamental activities that affect competitiveness. Over the years, companies realized that buying, producing and delivering goods to the point of sale require a multidisciplinary team approach. The complex decisions involved in the logistics processes and management of materials, quantities, costs and prices require a strategic vision. Thus, business activities have become much more complex than the simple decision to make, negotiate and deliver (McElhone, 1994).

From the 1980's on, new concepts such as green logistics and reverse logistics, which seek possibilities to recover materials and to value rejects, caused an increase in the number of studies on direct flows and returns, requiring additional and more specific considerations (Kokkinaki et al., 1999; Gungor \& Gupta, 1999; Fleischmann et al., 2000). At that time, the concept of green logistics was seen as a fad, even as a mere marketing appeal, or simply as a means to find a destination for waste, as observed by Rogers and Tibben-Lembke (1998), Gungor and Gupta (1999), and Fleischmann et al. (2000). Future studies should include the damage caused to the planet by the incorrect disposal of products, particularly those containing dangerous, harmful substances to humans and the environment. Rogers and TibbenLembke (2001) also emphasize reverse logistics as a profit generating function, which means that RL may be seen as a trade-off between economic and environmental sustainability.

Thierry et al. (1995) state that the objective of product recovery management "is to recover as much of the economic (and ecological) value as reasonably possible, thereby reducing the ultimate quantities of waste". According to this author, typically manufacturers simply ignore what their customers do with the purchased products after use. Many products are designed in such a way as to minimize production, manufacture, sales and distribution costs, and there is not even the slightest concern for reuse, repair or disposal of waste, because "manufacturers generally believed that the costs of incorporating these requirements would outweigh the benefits." (Thierry et al., 1995, p. 114). Besides, the higher costs of reverse logistics are emphasized by Leite et al. (2009) and Kaynak et al. (2014), as follows:

"The cost of RL is 9 times higher than the cost of forward logistics because the distribution of the new manufactured goods can be consolidated but as proposed earlier the consolidation of reverse delivery/ shipment is possible with the involvement of multiple firms and shared resources (e.g. trucks, inspection units, technology, equipment, facility)."

Equally, the technological progress from recent years allows for a new outlook on the so-called post-consumer waste, mainly due to the shorter life cycles and increased frequency and volume of disposed products and materials. Moreover, researchers and companies started to notice that many returned, or merely replaced, products are either still in working conditions or allow for repairing, renovation, cannibalization, recycling and recovery of materials and value, before their final disposal. In this sense it is possible to distinguish End of Life (EoL), when the product has exhausted its functions, from End of Use (EoU), when the product has lost functionality for the consumer. According to this view, Thierry et al. (1995) summarize the various options for the recovery of post-consumer waste, as illustrated in Table 1. 
Table 1. Product recovery options.

\begin{tabular}{cccc}
\hline $\begin{array}{c}\text { PRODUCT } \\
\text { RECOVERY } \\
\text { OPTIONS }\end{array}$ & $\begin{array}{c}\text { LEVEL OF } \\
\text { DISASSEMBLY }\end{array}$ & $\begin{array}{c}\text { QUALITY } \\
\text { REQUIREMENTS }\end{array}$ & $\begin{array}{c}\text { RESULTING } \\
\text { PRODUCT }\end{array}$ \\
\hline Repair & To product level & $\begin{array}{c}\text { Restore product to } \\
\text { working order }\end{array}$ & $\begin{array}{c}\text { Some parts fixed or } \\
\text { replaced by spare }\end{array}$ \\
\hline Refurbishing & To module level & $\begin{array}{c}\text { Inspect all critical } \\
\text { modules and upgrade to } \\
\text { specified quality level }\end{array}$ & $\begin{array}{c}\text { Some modules } \\
\text { repaired/replaced; } \\
\text { potential upgrade }\end{array}$ \\
\hline Remanufacturing & To part level & $\begin{array}{c}\text { Inspect all modules and } \\
\text { parts and upgrade to } \\
\text { as new quality }\end{array}$ & $\begin{array}{c}\text { Used and new } \\
\text { modules/parts combined } \\
\text { into new product; } \\
\text { potential upgrade }\end{array}$ \\
\hline Cannibalization & Selective retrieval of parts & $\begin{array}{c}\text { Depends on process in } \\
\text { which parts are used }\end{array}$ & $\begin{array}{c}\text { Some parts reused; } \\
\text { remaining product } \\
\text { recycled/disposed }\end{array}$ \\
\hline Recycling & To material level & $\begin{array}{c}\text { High for production of } \\
\text { original parts; } \\
\text { less for other parts }\end{array}$ & $\begin{array}{c}\text { Materials reused to } \\
\text { Produce new parts }\end{array}$ \\
\hline
\end{tabular}

Source : Thierry et al., 1995.

Economic issues, along with social and environmental conditions, tend to favor the reuse of products and materials as a way of maintaining sustainability standards. In this context, Kokkinaki et al. (1999), based on the model of Integrated Supply Chain and the taxonomy of reverse flow processes proposed by Thierry et al.(1995), expand the reuse (second life) approach according to the model in Figure 1. The authors include the Internet as a way to connect buyers and sellers through e-commerce, facilitating Consumer to Consumer ( $\mathrm{C} 2 \mathrm{C})$ transactions and providing rapid flow, recovery and reuse of secondary market products, post-consumer waste and end of life products, also considering the return of materials and waste disposal. 
Figure 1. Product Flow in Supply and Recovery Chain

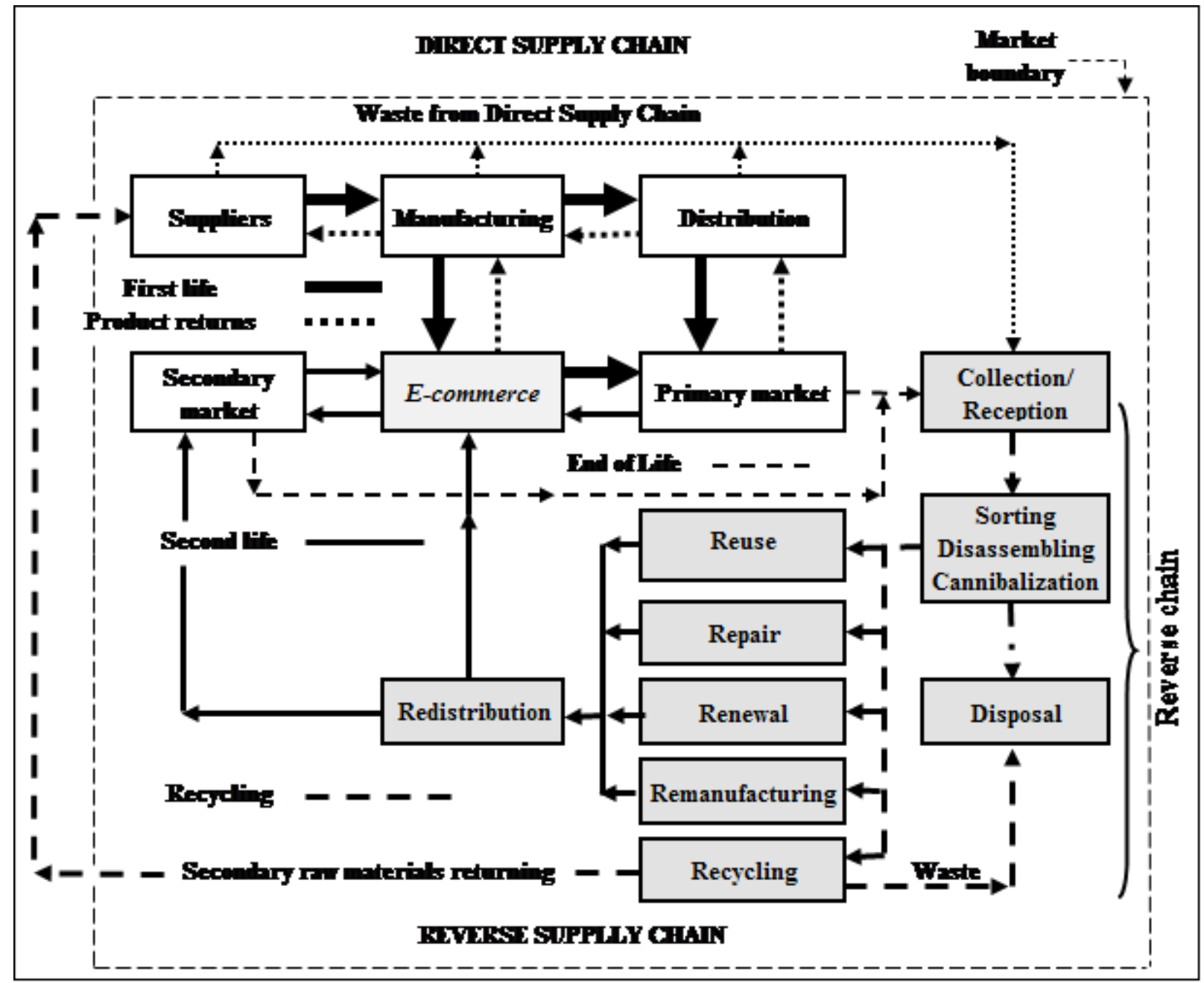

Source: Adapted by the authors from Kokkinaki et al. (1999).

Direct logistics activities are represented by the first sequence of blocks on the upper half of Figure 1. The second row of blocks represents interactions among market players: primary market (first buyer), secondary market (two or more subsequent purchasers), e-commerce and waste collection/reception. The bottom half features the activities of reverse logistics and recycling in general, namely: reuse, repair, refurbishment, remanufacturing, recycling and proper disposal of waste.

Expanding on the work by Kokkinaki et al., (1999), Figure 1 also describes the primary and secondary markets, expanding the product Life Cycle Assessment (LCA) approach (González-García et al., 2012). We consider a new taxonomy, not only the boundaries of 'cradle to gate' or 'cradle-to-point' of consumption (cradle to site) and 'cradle to grave', but reverse logistics in closed loop or 'cradle to cradle ${ }^{\circledR \prime}$ as per McDonough and Braugart (2002).

Clearly, some concepts have changed, such as postconsumer waste, which may be seen as secondary raw materials. New paradigms emerged or gained force in the legal, operational and managerial fields, such as the alternatives of reuse, refurbishing, recycling, remanufacturing, etc. In this regard, some cases were highly successful in Brazil, such as postconsumer aluminum cans (Shinzato and Hypolito, 2005; Almeida et al., 2010), agrochemicals (Sato et al., 2006; Duarte et al., 2009) and lubricant packaging recycling (Gomes et al., 2008).

Knowledge about the possibilities of reinserting post-consumer waste into the cycle has increased; however, it has not totally overcome business man- 
agers' distrust in the opportunities arising from reverse logistics. Braga Júnior et al. (2006) argue that companies do not have appropriate systems for measuring the economic impact of product return and possible reuse, and that reverse logistics is understood as a high-cost, non-essential, non-strategic operation. Other authors explain business lack of interest in reverse logistics not only because of the costs involved, but also due to the complexity in coordinating different supply chain stakeholders, such as distributors, retailers, consumers, and collecting and recycling organizations. To Jayaraman and Luo (2007), this complexity is associated with the need to establish new relationships between several players in the production chain, which requires additional coordination efforts by companies.

As demonstrated by Demajorovic et al. (2012), the need to develop an infrastructure to collect post-consumer waste, to identify alternatives to ensure the reuse of materials, or to securely dispose of waste are strange activities to most companies. Thus, when evaluating and implementing a reverse logistics program, the challenges are seen more clearly than the opportunities - such as anticipating the legislation (Stock \& Mulki, 2009), reaping benefits to company image (Ravi et al., 2008; Leite et al., 2009) and gaining opportunities to reduce costs and increase competitiveness through product and process re-design (Jayaraman \& Luo, 2007). In this context, the law continues to be the major stimulus for the development of reverse logistics in business management, as stated by Lau and Wang (2009). However, the same authors add that, even in developed countries, it is also necessary to proceed with tax incentives for recycling post-consumer waste.

The challenges discussed above are also the reality in developing countries. However, in addition to the strategic, economic and technical aspects, the social issues in managing reverse chains in developing countries gain importance, because many of such chains are sustained by the actions of informal agents. It is important to remember, as shown by Ribeiro et al. (2009), that the largest share of waste returned for recycling in Brazil is the work of waste and recyclable materials pickers.

It is estimated that, in Brazil, there are 1 million waste pickers, of whom only ten percent work at recycling cooperatives (MNCR, 2014). The other 90 percent are self-employed and perform their daily tasks with little regard to health, safety and environmental protection (Schluep et al., 2009). The NPSW is an advancement in recognizing these workers as one of the country's essential elements in achieving effective reverse logistics for materials such as plastics, paper, aluminum cans and e-waste.

However, it should be noted that WEEE requires special care for its reuse. Unlike most materials handled by scavengers, such as plastics, metal, paper and PET bottles, WEEE has the potential to cause severe problems to human health and to the environment during its dismantling and separation. In terms of the prospects for reusing this material, "roughly speaking, WEEE consists of three major parts: 40:30:30 - metal, plastics and refractory oxides, respectively" (Sodhi \& Reimer, 2001, p. 99). Several authors emphasize mobile phone and computer electronic circuit boards as the components with higher added value in proportion to their weight, due to the higher concentrations of precious and strategic metals. (Leite et al., 2009; Franco et al., 2011; Yamane et al., 2011; Zeng et al., 2012; Henrique Júnior et al., 2013; Petter et al., 2014).

Nevertheless, properly recovering valuable materials also requires training and expertise. Various kinds of materials are complex, sometimes harmful and toxic, and cannot be handled by untrained workers, as they pose great risks to all involved in this process (ABNT NBR 16.156:2013). Substances such as lead, barium, beryllium, cadmium, chromium and mercury from computers have the potential to both pollute water, soil and air, and to severely intoxicate workers who handle them improperly, even causing death in some specific cases. Shane (2011) argues that burning electronic components for recycling and disposal in open areas near poor populations are common practices in developing countries, which cause serious health problems to these communities.

An important strategy to prevent and/or mitigate these potential socio-environmental risks is the adoption of Green IT or CIT Sustainable Design concepts, as promoted by the Institute of Electric and Electronics Engineers (IEEE), referred to by Mureguesan and Laplante (2011): "designing, manufacturing, using, and disposing of computers, servers, and associated subsystems - such as: monitors, printers, storage devices, networking and communications systems - efficiently and effectively with minimal or no impact on the environment".

In order to promote reverse logistics and mitigate post-consumption environmental and social impacts, the Brazilian National Policy for Solid Waste 
(NPSW) was passed in 2010. Besides introducing some of the concepts and strategies already described, this law established a system of shared responsibility for managing various kinds of postconsumer waste, including Waste of Electrical and Electronic Equipment (WEEE).

\section{NATIONAL POLICY FOR SOLID WASTE (NPSW) FEATURES}

The NPSW established a new regulatory framework for the Brazilian society, providing an appropriate destination for solid waste generated by manufacturing and disposing of several goods, including electro-electronic equipment, which is the focus of the present work. It also established the obligation to implement and operate Reverse Logistics Systems (RLS) aimed to collect, assign, reintegrate and reuse waste along supply chains. The NPSW instructs on how to dispose of the waste resulting from these processes in environmentally correct ways, and it promotes the social inclusion of legally constituted picker groups.

Although the passing of the new law has been quite a slow process, taking about 20 years, Reveilleau (2011, p. 164) highlights its importance for Brazil, because "one of the obstacles was the lack of a nationwide standard focusing primarily on waste management, and assigning responsibilities to generators, consumers and government authorities". In this context, we highlight some of the main advances that are of interest for this research. The first point is the recognition that the proper management of post-consumer waste must be shared by the many players involved in the recycling chain:

XVII - shared responsibility for product life cycle: a set of individual and chained assignment of manufacturers, importers, distributors, retailers, consumers, and members of public urban sanitation and solid waste management, to minimize the volume of waste and solid waste generated, as well as to reduce the impacts to human health and the environment resulting from product life cycles, in the terms of this Act (Brazil, 2010a);

The recognition of the need for shared responsibility is essential to the advancement of waste management in the country, as the proper disposal of waste depends on the collaboration of all the chain players, including manufacturers, the public sector, retailers and consumers.
The NPSW also breaks new ground by recognizing groups of recyclable materials as legally relevant to RLS actors, and by encouraging their involvement in various initiatives to expand waste collection and disposal. Still, perhaps, the main innovation is the definition of tools to operationalize reverse logistics, among which is the establishment of sector agreements, which are defined as:

I - sector agreement: contract signed between the government and manufacturers, importers, distributors or retailers, with a view to implement shared responsibility for the product life cycle (Brazil, 2010a);

It is expected that the target of improving solid waste management in the country will be achieved with the sector agreements, since they are the result of dialog among all the players involved in the reverse chain. Proposals for implementing reverse logistics are set in various sector agreements, based on the concern for social and environmental management contained in the legal reverse logistics definition:

XII - Reverse logistics: instrument characterized by a set of actions, procedures, and means included in economic and social development programs, aimed to enable the collection and return to the business sector of solid waste either for reuse in their production cycle, or in other production cycles, or for final disposal in environmentally appropriate ways (Brazil, 2010a);

Reverse logistics is considered one of the most controversial issues of the new law, because there was great resistance from the business sector to accept responsibility in managing post-consumer waste, due to the complexity and costs involved in this activity (Demajorovic \& Migliano, 2013). Article 33 in the national policy states that: post-consumer electronic products and their components should be recovered by manufactures, importers, distributors or retailers, independently of public urban cleaning services. The hierarchy of requirements for using and processing post-consumption products and materials among the different players in the supply chain, who are co-responsible for the shared management of product life cycle is: no generation, reduction, reuse, recycling, treatment and final disposal.

The Brazilian solid waste management act seems to be heterogeneous, as compared to state laws. However, the NPSW tends to impose some uniformity to decision requirements. As stated by Rev- 
eilleau (2011), one of its greatest contributions was a nationwide waste regulation. The hierarchy of post-consumer materials and products, as stated by the NPSW, is based on previous international legal documents and also on the work of leading authors such as Thierry et al. (1995), Rogers and TibbenLembke (1998) and Kokkinaki et al. (1999), to name a few. In its Article 9, besides its Regulations (Decree 7.404/2010, Title IV, Articles 35 to 39), the NPSW considers both the concepts of reverse logistics in open-loop (similar to direct logistics) and closedloop (closed-loop supply chain), giving rise to the fundamental '3Rs' of reverse logistics, namely:

a) reduce: either the consumption of raw materials, recycled materials, energy, or the actual generation of waste, by improving or developing processes; b) reuse: extending product or component life cycle, or developing a market for second-hand goods, either repaired or refurbished, through the reuse of post-consumption goods or components obtained by means of cannibalization or recycling processes;

c) recycle: reusing materials and energy when technical, economic and environmental processes permit reducing the volume of waste requiring final disposal.

To this end, the NPSW in its Article 54 establishes deadlines for implementing sector agreements among all the players involved. For the electro-electronics industry, the deadline for the sector agreement was established within 4 years after the NPSW enactment. In Figure 2, Corrêa and Xavier (2013) propose an interpretation of the responsibilities assigned to stakeholders involved in the implementation of RLS.

Figure 2. NPSW stakeholders' shared responsibility for RLS.

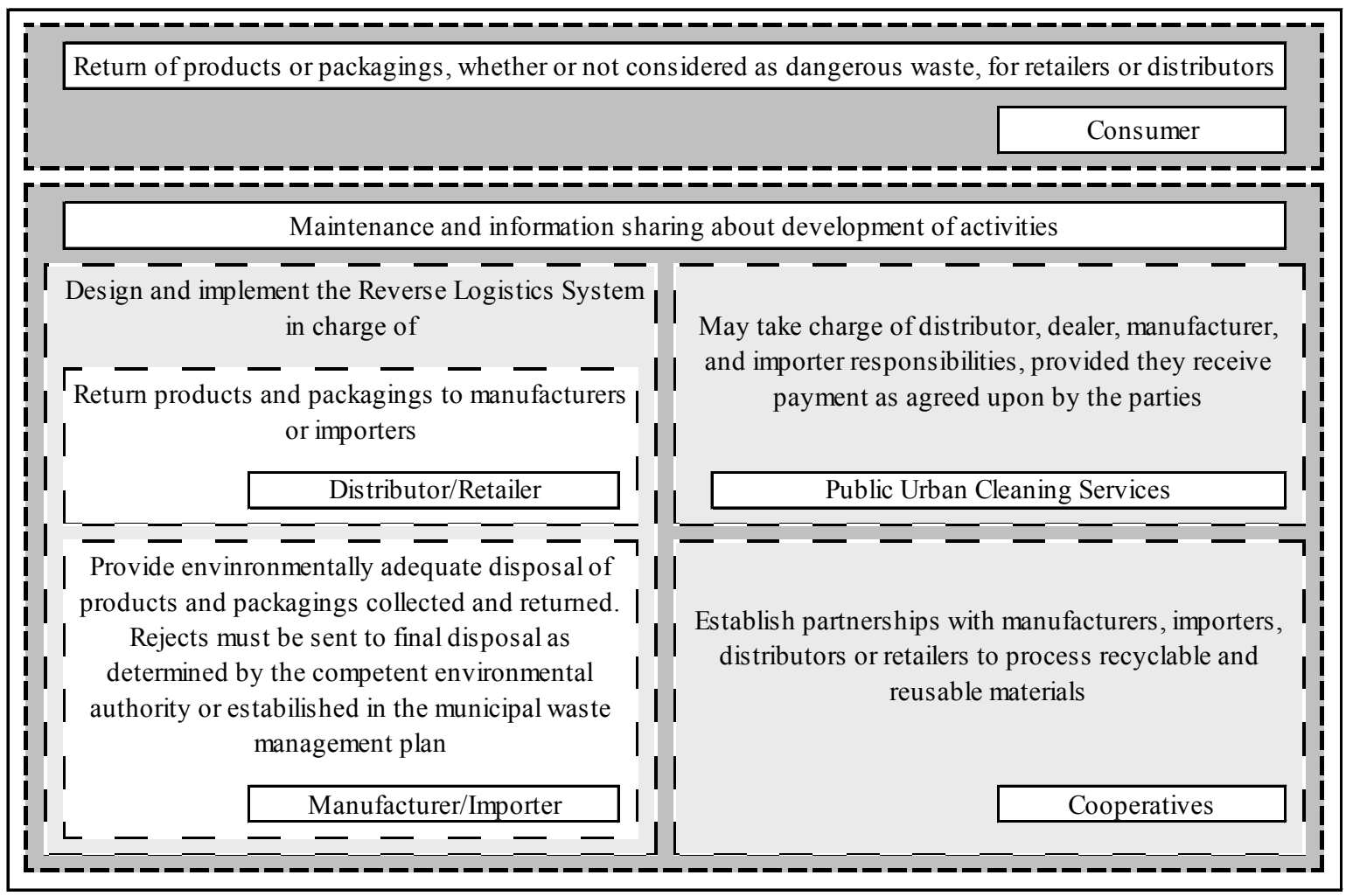

Source: Corrêa and Xavier, 2013 
Figure 2 shows that consumers' sole responsibility is to deliver post-consumer waste. On the other hand, public cleaning services only responsibility in the system is to collect post-consumption materials and products, to the extent that they are paid for it.

Associations and cooperatives should work to establis partnerships. In a nutshell, manufacturers, importers, distributors and retailers should be accountable for effectively implementing the Reverse Logistics System. This interpretation represents a new dimension to the proposal of shared responsibility, defining the degree of responsibility of each agent in the reverse chain.

The discussion above raises important issues regarding the implementation of reverse logistics in Brazil. Lau and Wang (2009) sustain that in developing countries it is essential to promote cooperation between companies, public sector and non- governmental organizations, in order to reduce the resistance of the private sector to implement reverse logistics. The NPSW has as one of its key points to promote cooperation among reverse logistics chain members. But guaranteeing this cooperation is not an easy task, even when required by law. Rotter et al. (2011) show that, despite demands from the European Directive, a shared responsibility model to implement a system for WEEE collection and treatment raised conflicts among manufacturers and retailers about transportation costs - even in developed countries. Augusto (2014) also identified the same conflict in the Brazilian scenario in her research on the national model for shared responsibility in WEEE. In Brazil, another important challenge in complying with the legislation is to make producers and waste picker organizations work effectively together.

Jesus and Barbieri (2013) sustain that waste picker organizations tend to reduce their vulnerability when they are successfully incorporated into manufacturer reverse logistics flows as suppliers of recyclable materials. But, building such partnerships faces a series of problems, because many waste picker organizations lack professional management processes and a legal business structure. Also, mis- understandings and conflicts are common in the relationship between the two stakeholders (Souza et al., 2012; Demajorovic and Migliano, 2013; Jesus \& Barbieri, 2013). Therefore, it is important to question whether the Brazilian legislation, based on shared responsibility, has been effective to motivate members of the WEEE reverse chain to engage in reverse logistics initiatives. It should be noticed that some articles on WEEE consumption and reverse logistics in Brazil have been published (Silveira \& Chang, 2010; Araújo et al., 2012; Mazon et al., 2012; Oliveira et al., 2012; Zanghelini et al., 2014). Nevertheless, few of them address the issue of deploying WEEE processes. As it is a fairly recent topic in the Brazilian literature, we decided to run a qualitative study to explore the operational, managerial and legal requirements.

\section{METHOD}

As previously mentioned, few authors have considered the application of WEEE management in Brazil. In this paper, we propose an interpretative, qualitative study in order to evaluate stakeholders' perceptions.

Therefore, we chose to discuss this process from the perspective of the players involved in the WEEE reverse logistics chain and in the development of sector agreements. The researchers' participation in the meetings held by the Brazilian Association for Technical Standards (ABNT) was crucial to witness the discussions precisely when they were being held by key decision makers from all the segments involved in the construction of Reverse Logistics Systems (RLS) for waste management. These discussions occurred along one year and were the basis for outlining the sector agreements, which have not been formalized yet.

Besides participating in ABNT meetings, primary data collection included a set of 21 interviews with: government officials, manufacturers, recycling firms, and waste picker cooperatives, as well as with academicals working on this theme, as shown in Table 2: 
Table 2. Codification and distribution of interviewees

\begin{tabular}{lcc}
\hline PLAYERS & QUANTITY & PARTICIPATION \% \\
\hline Government (G1 to G3) & 3 & 14,3 \\
\hline Manufacturers (M1 to M5) & 5 & 23,8 \\
\hline Recyclers (R1 to R6) & 6 & 28,6 \\
\hline Cooperatives (C1 to C4) & 4 & 19,0 \\
\hline Academia (A1 to A3) & 3 & 14,3 \\
\hline Total of interviews & $\mathbf{2 1}$ & $\mathbf{1 0 0 , 0}$
\end{tabular}

Source: Developed by the authors.

The individuals to be interviewed were chosen using an intentional sampling procedure. This methodological approach was considered important in order to guarantee that the key sectors and agents involved in the sector agreement were represented in the survey. The researchers' participation in the ANBT forum, as stated above, helped to select the first individuals to be interviewed. After that, using the snow-ball technique, additional subjects were identified to join the final sample (Bailey, 1994). Still, according to Bailey (1994), such a small and nonprobabilistic sample does not permit further statistical analyses, even though it is adequate in a preliminary exploratory approach that could be followed by a more extensive survey.

We promised the interviewees and their organizations that their identities would be kept confidential (Bailey, 1994; Godoi \& Balsini, 2010).

A set of seven open-ended questions were prepared based on the literature review, the NPSW study and discussions form the ABNT forum. They included themes such as: the importance of the new law, its effectiveness in handling WEEE, the proposed timetable for its implementation, and the participation of waste picker cooperatives in RLS, among others. These questions were pre-submitted to the selected stakeholders before the interview.

The interviews were taped whenever agreed upon. The transcripts omitted any information that could identify individuals, companies or organizations, and were submitted for interviewee approval after being properly coded and numbered according to their chronological order of execution.

We chose the method of content analysis as proposed by Bardin (2002). It is defined as a set of analytical techniques that enable communications to reach logical and justified conclusions from the content of sender messages. A key element in content analysis is the creation of categories. Based on the literature review, the following categories and sub-categories were defined, as presented in table 3.

Table 3. Categories, subcategories and corresponding authors

\begin{tabular}{ccc}
\hline CATEGORIES & SUBCATEGORIES & AUTHORS \\
\hline NPSW & Importance of Legislation & $\begin{array}{c}\text { Reveilleau, 2011; Araujo et al., 2012 } \\
\text { Demajorovic \& Migliano, 2013 }\end{array}$ \\
\hline $\begin{array}{c}\text { Sector Agreement } \\
\begin{array}{c}\text { Shared Responsibility } \\
\text { Model }\end{array}\end{array}$ & $\begin{array}{c}\text { Participatory approach } \\
\text { Conflicts }\end{array}$ & $\begin{array}{c}\text { Reveilleau, 2011; } \\
\text { Corrêa \& Xavier, 2013 }\end{array}$ \\
\hline
\end{tabular}




\begin{tabular}{ccc}
\hline & Costs & Thierry et al., 1995; Braga Junior et al., \\
Reverse Logistics & Technological aspects & 2006; Stock \& Mulki, 2009; Wagner, 2009; \\
& Transportation & Lau \& Wang, 2009 \\
\hline \multirow{2}{*}{ Waste pickers } & Health and environmental risks & Schluep et al., 2009; Shane, 2011; \\
& Conflicts & Wang et al., 2012; Souza et al., 2012; \\
& Challenges & Jesus \& Barbieri, 2013 \\
\hline
\end{tabular}

Source: Developed by the authors.

Then the transcripts were examined, seeking for full elements or themes corresponding to the context. They were subsequently categorized and listed to identify agreements, contrasts and disagreements among respondents from the same group of actors, but also between different players.

The analysis of the transcripts also included a vertical analysis of materials collected from the different players, in order to identify conflicts and different views or positions on the researched themes. The most important findings from this process are brief- ly commented in the next topic.

Additionally, after concluding the above tasks, all the transcripts (more than 72,000 typed words) were screened using Microsoft Office tools. The content analysis method considers a word and its possible variants, for example, "to process" and "processing". About 897 very frequent words were identified after a systematic screening of the universe. A relevant fragment of this list of words and their corresponding distribution among interviewees is shown in Table 4:

Table 4. Fragment of the list of most relevant words

\begin{tabular}{|c|c|c|c|c|c|c|c|c|c|c|c|c|c|}
\hline \multirow{2}{*}{$\begin{array}{c}\text { Most } \\
\text { frequent } \\
\text { words }\end{array}$} & \multicolumn{3}{|c|}{ Total } & \multicolumn{2}{|c|}{ Government } & \multicolumn{2}{|c|}{ Manufacturer } & \multicolumn{2}{|c|}{ Recycler } & \multicolumn{2}{|c|}{ Cooperative } & \multicolumn{2}{|c|}{ Academia } \\
\hline & $\begin{array}{c}\mathrm{Q}^{1} \\
\mathbf{8 9 7}\end{array}$ & $\begin{array}{c}\% \\
100\end{array}$ & $\mathrm{CF}^{2}$ & $\begin{array}{c}\mathrm{Q} \\
163\end{array}$ & $\begin{array}{c}\% \\
100\end{array}$ & $\begin{array}{c}\mathrm{Q} \\
238\end{array}$ & $\begin{array}{c}\% \\
100\end{array}$ & $\begin{array}{c}Q \\
241\end{array}$ & $\begin{array}{c}\% \\
100\end{array}$ & $\begin{array}{c}\mathrm{Q} \\
153\end{array}$ & $\begin{array}{c}\% \\
100\end{array}$ & $\begin{array}{c}\mathrm{Q} \\
101\end{array}$ & $\begin{array}{c}\% \\
100\end{array}$ \\
\hline Process & 190 & 21.2 & 21.2 & 37 & 22.7 & 65 & 27.3 & 44 & 18.3 & 31 & 20.3 & 13 & 12.9 \\
\hline Consumption & 123 & 13.7 & 34.9 & 13 & 8.0 & 27 & 11.3 & 38 & 15.8 & 28 & 18.3 & 17 & 16.8 \\
\hline Discussion & 84 & 9.4 & 44.3 & 25 & 15.3 & 32 & 13.4 & 15 & 6.2 & 10 & 6.5 & 2 & 2.0 \\
\hline Costs & 79 & 8.8 & 53.1 & 5 & 3.1 & 17 & 7.1 & 38 & 15.8 & 16 & 10.5 & 3 & 3.0 \\
\hline Information & 58 & 6.5 & 59.6 & 5 & 3.1 & 7 & 2.9 & 27 & 11.2 & 7 & 4.6 & 12 & 11.9 \\
\hline Education & 51 & 5.7 & 65.3 & 16 & 9.8 & 9 & 3.8 & 6 & 2.5 & 15 & 9.8 & 5 & 5.0 \\
\hline Technology & 46 & 5.1 & 70.4 & 24 & 14.7 & 4 & 1.7 & 3 & 1.2 & 8 & 5.2 & 7 & 6.9 \\
\hline Control & 27 & 3.0 & 73.4 & 2 & 1.2 & 9 & 3.8 & 9 & 3.7 & 7 & 4.6 & 0 & 0.0 \\
\hline Awareness & 26 & 2.9 & 76.3 & 7 & 4.3 & 10 & 4.2 & 3 & 1.2 & 0 & 0.0 & 6 & 5.9 \\
\hline Investment & 26 & 2.9 & 79.2 & 4 & 2.5 & 6 & 2.5 & 6 & 2.5 & 6 & 3.9 & 4 & 4.0 \\
\hline Resources & 26 & 2.9 & 82.1 & 8 & 4.9 & 5 & 2.1 & 4 & 1.7 & 4 & 2.6 & 5 & 5.0 \\
\hline
\end{tabular}

Source: Developed by the authors.

Notes: 1 = Quantity; 2 = Cumulative Frequency; Most relevant 
A few of the most representative words in Table 4, in decreasing levels of importance, are commented below:

- Process: with a 21.2 percent frequency, it expresses the most important concerns of Government officials, Manufacturers, Recyclers and Cooperatives regarding the NPSW implementation process, the distribution of responsibility among the players, the WEEE reverse logistic process, the inclusion of waste pickers in these tasks, and so on. For the Academicals, it was the second most important point of concern;

- Consumption: in the sense of consumer, consumption and similar meanings, with a 13.7 frequency, but not so relevant for the Government representatives, reaching only 8.0 percent;

- Discussion: in the sense of discussion, discussing processes and similar terms, with 9.4 percent. It is important to stress that the word dialog did not appear in the amount of more than 72,000 words;

- Costs: in the sense of processing cost, logistics costs involved in returning goods and other similar meanings, with 8.8 percent;

- Technology: it appears only in the $6^{\text {th }}$ position, but it is a strong concept in Government officials' discourse. It may be related to the importance of technology in providing sustainable solutions for WEEE management.

And finally, the word information, with a 6.5 percent frequency, was mostly related to information on how consumers should proceed with end-of-life electric and electronic equipment.

\section{CHALLENGES AND PERSPECTIVES FOR WEEE REVERSE LOGISTICS IN BRAZIL: PERCEPTIONS OF STAKEHOLDERS}

Our research showed that, for the respondents, NPSW adoption represents one of the most important events in the evolution of solid waste management models in Brazil, because it established a uniform, national rule, thus eliminating isolated actions, regulatory discrepancies, or omissions by state governments. Regional differences were leading companies to make deployment decisions or to migrate to geographical areas with less restrictive public policies. This aspect of the NPSW was unanimously mentioned by the subjects, who emphasized the importance of establishing country-level rules and deadlines for solid waste management. Although most states still lack a specific regulation for WEEE management, it is noteworthy that the federal government is now committed to it, due to the private sector's engagement. Companies have become interested in WEEE management as a way to improve their corporate image, and also as an alternative to get profits from secondary raw materials.

Also, very relevant aspects in the adoption of NPSW are the obligation to implement reverse logistics and the recognition of the need for shared responsibility among all the stakeholders in different production chains (the manufacturers, the public sector, retailers, consumers and waste pickers). The survey revealed that the sector agreements are valued by different chain stakeholders, as they promote dia$\log$ and contribute to shared accountability for the product life cycle. However, in the case of electronic waste many obstacles remain to be overcome, despite such advancements.

First, it is clear for all participants that encouraging a dialog among e-waste reverse chain members gives rise to new challenges caused by conflicting interests and the difficulty to reach a consensus. This obstacle to NPSW implementation is evidenced by the slow evolution of sector agreements, especially in the area of technological waste, as mentioned by allrespondents. It appears that, although the sector agreement may provide a valuable collective commitment, conflicts of interest and disagreements prevent reverse logistics programs from advancing faster in Brazil. So, the deadline established in the NPSW will probably be compromised due the extension of the debate.

Secondly, manufacturers' resistance to incorporate the costs of implementing reverse logistics, as already mentioned in previous works by Thierry et al.., (1995), Braga Junior, Costa and Merlo (2006), Stock and Mulki (2009) and Wagner (2009), is a major impediment in the current scenario, in the perception of industry representatives, recyclers and cooperatives. Even though most of the Brazilian market is dominated by international computer manufacturers, who are also present in several developed countries, the industry does not perceive NPSW as an opportunity, and thus does not consider it in their business plans. Also, the coordination problems and conflicts between producers and retailers identified in this study corroborate findings by Jayaraman and Luo (2007), Rotter (2011), and Augusto (2014). The 
interviews have shown that, although the legislation requires a shared responsibility model, manufacturers and retailers fail to reach an agreement as to whom should bear transportation costs to recycling centers. As the NPSW does not clearly state who shall be responsible for this, both sectors use the gaps in the legislation to transfer accountability and to postpone a final agreement.

A third and important issue is the gray market. It comprises irregular, but not always illegal, products that represent a significant part of the Brazilian computer market. The main question here is who should be in charge of this kind of post-consumer waste. Manufacturers tend to avoid handling postconsumption gray market products, because they entered the country without paying the required imports duties and local taxes.

Fourth, the large size of the Brazilian territory is also a challenge for the success of local logistics initiatives, as collection activities become even harder outside major cities. It cannot be overemphasized that the volume of recyclable materials available and their financial value are essential to generate economies of scale and to ensure the financial feasibility of reverse logistics. In the Brazilian context, the problem with long distance transportation costs and the technological gaps should also be considered. The recycling technology available in the country is for lower-value components only, such as plastic and metal. Printed Circuit Boards (PCB) can only be separated locally, and then shipped abroad for recovery, thus transferring to developed countries most of the value generated by recycling.

It is worth noting that the current Brazilian tax structure does not offer any kind of tax exemption or compensation for recyclable products; also, there is a lack of financial instruments to promote reverse logistics, as confirmed recently in a report published by the National Industry Federation (CNI, 2014). Lau and Wang (2009) sustain that tax incentives for recycling post-consumer waste is an essential tool for the success of reverse logistics initiatives. The CNI supports creating a fee for the purchase of electrical and electronic goods to cover the recycling costs at the end of their life cycle, which consumers should be informed of at the moment of purchase. In fact, this proposal was already included in the sector agreement. But the interviewees showed low optimism that, given the current Brazilian tax system, this visible fee could be effectively implemented. . Therefore, it is very unlikely that feasible WEEE collecting and recycling programs are implemented by the manufacturers.

Finally, one of the main obstacles to implementing NPSW is precisely one of its most innovative features: the recognition of the key role played by waste picker organizations in reverse logistics initiatives (Souza et al., 2012). Selling directly to recyclers can substantially impact waste pickers' income (Jesus \& Barbieri, 2013) It can be argued that reverse logistics in the computer and electronics markets may foster social inclusion in developing countries. But the characteristics of e-waste and companies' low interest in working together with waste picker organizations are a challenge to this. As previously discussed, electronics are not hazardous to the environment or to human health throughout their product life cycle, but disassembling e-waste for reuse poses a series of environmental threats, and thus require a well-trained workforce, and special care.

The interviewees, including waste picker organizations and government representatives, agreed that few cooperatives possess the necessary qualifications to do WEEE recycling. In this sense, although the legislation is an important step, skill building and training efforts appear as essential complementary actions, reinforcing the results of the research by Schluep et al. (2009) and Shane (2011).

Based on the challenges presented above, we argue that the model for shared responsibility constructed by means of sector agreements, as proposed by the NPSW (as shown in Figure 3), is not comprehensive enough to deal with the complexity of the Brazilian WEEE reverse chain.

So, based on the literature review and on our research, we propose a broader model, encompassing all the agents that interfere directly, indirectly, locally and internationally with the electronics reverse chain. 
Figure 3. Hypothetical closed-loop supply chain model for WEEE in Brazil

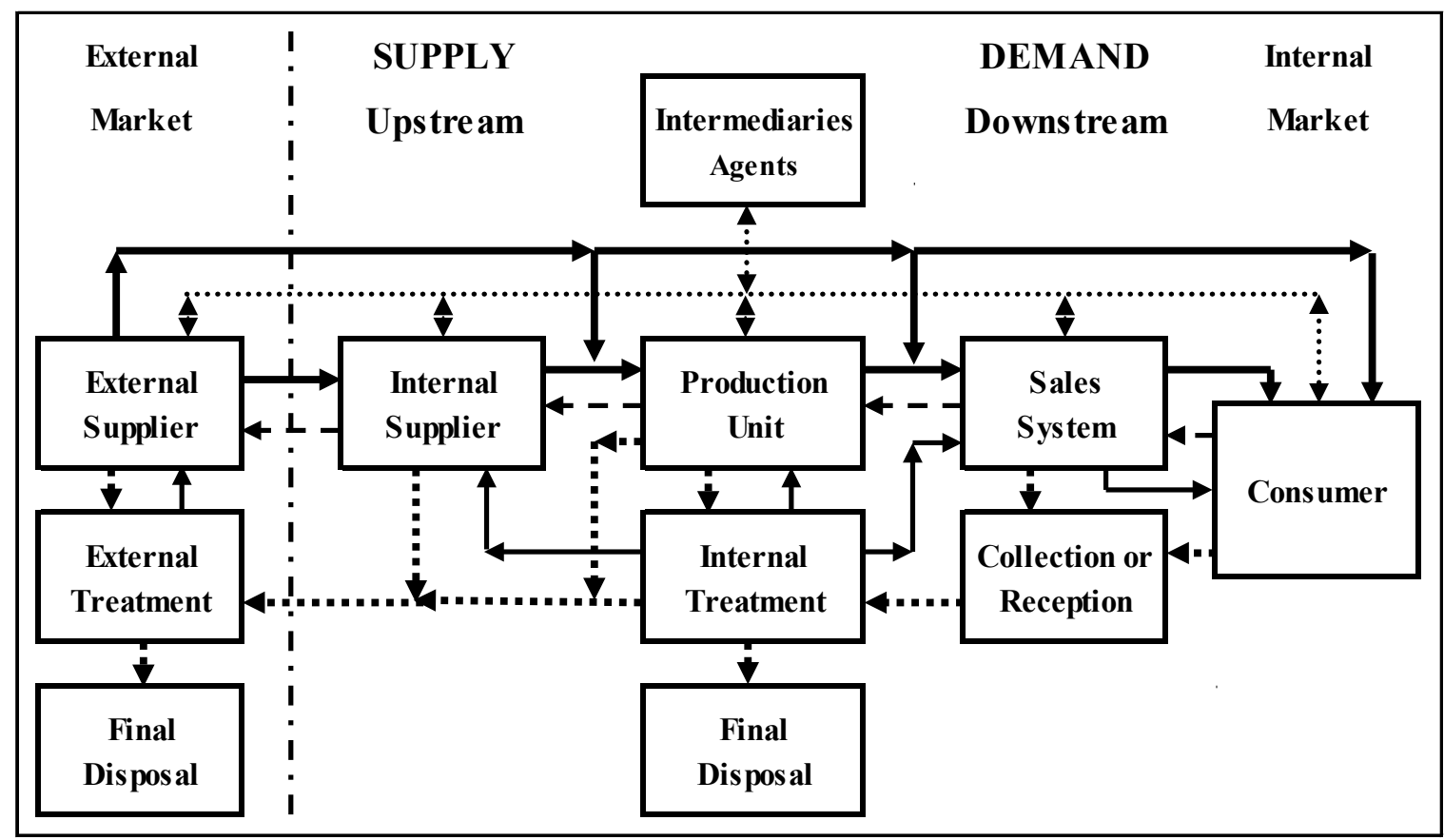

Source: Developed by the authors.

The diagram in Figure 3 illustrates the complexity of the Brazilian situation, starting with the element on the upper left side: the external market, limited by the customs barrier represented by the dash-dotted line on its right side. The internal suppliers are positioned upstream along the production chain; moving downstream we find the demand system, and finally the end consumers in the internal market.

The central block at the top of the diagram corresponds to intermediaries, who are involved in various processes. Examples are providers of supporting services, usually outsourced by the companies, such as: customs brokers, transportation services, financial support and market research, among others (Lambert \& Cooper, 2000). The interactions of these service providers with the other agents that participate directly in the activities, whether direct or reverse, are represented by a single dotted line.

The blocks on the middle line, from left to right, correspond to: the foreign supplier, its domestic equivalent, the production unit, the sales system and the end consumer. They comprise the set of players who participate in the direct supply chain. As an example of the Brazilian case, an outside vendor can directly provide a finished product to the client via e-com- merce, with home delivery; this situation is represented in the diagram by the first set of direct arrows from left to right, representing a direct flow.

As illustrated by the arrows in the diagram, an external supplier can also directly provide a local company, a manufacturer, one of their suppliers, or even the sales system, with modules that perform specific functions or assemblies, subassemblies, components, or even isolated parts. The arrows and dotted lines between the blocks reflect the interactions among the supply chain players for (i) value adding transactions in the direct flow and (ii) treatment of both non-conformities and post-consumption goods in the reverse flow.

The sales system includes sales and after-sales services, as well as the internet. The web permits, for instance, that an end user re-sells and returns a used product to the market, thus extending its life cycle. This possibility is represented by the first arrow in the reverse direction connecting the distribution system to the end customer.

In the diagram, the same arrow can also represent a second reverse flow, which corresponds to returns due to non-conformity or warranty services, 
or for maintenance and repairs after the warranty period has expired. Thus, a variety of stakeholders involved in the electronics reverse chain need to be considered for planning and executing a RLS, in order to effectively implement NPSW.

\section{CONCLUSIONS}

Today, Brazil is one of the world's major IT markets. This industry generates increasing amounts of postconsumer waste, which require proper disposal to minimize their environmental impacts. This is necessary to comply with the NPSW requirements and, more specifically, to contribute to RLS implementation. The findings from this research show that the new legislation is an important step in this direction. Respondents agree that the sector agreements foster a dialog between different stakeholders in the reverse logistics chain, which is essential to build a shared responsibility model for the electrical and electronic equipment life cycle.

However, this participatory approach faces several challenges and threats to reaching its objective. We argue that the model of shared responsibility being developed is not comprehensive enough to deal with the complexity of the Brazilian WEEE reverse logistics chain. Therefore we presented a broader model covering all the different players involved in both the direct and reverse flow of goods, according to the closed-loop concept.

This model represents the managerial aspects involved in coordinating the necessary interactions and transactions among the players in the direct and reverse logistics flows. The proposed model highlights the complexity of the reverse logistics flow, because it shows that end-of-use products are not always processed within the original delivery system. WEEE requires workers with specific information and operational training, as well as a technological infrastructure to process waste in an environmentally appropriate way. Another point of paramount importance to succeed in implementing RLS in Brazil is consumer awareness of the hazardous substances contained in WEEE, and their potential risks. Therefore, clear information on how consumers should properly handle WEEE is mandatory to stimulate their participation in reverse logistics initiatives.

However, consumer participation in RLS poses several other challenges in Brazil. Consumers are the final link on the direct chain and also the first one on the reverse flow. Nevertheless, they are spread out in more than 5,500 cities, most of them very far from the few recycling companies already existing in the country. Shipping services costs in Brazil are prohibitive in terms of transport modes and fuel consumption, as distances among the cities are normally long. The results suggest that, in the absence of legal requirements, the higher costs of reverse logistics, coupled with the long distances to be covered in a country like Brazil and with inefficiencies in transportation modes, tend to discourage manufacturers from investing in their own projects. In this context, our model contributes by providing an integrated overview of the interactions under the closed-loop concept. The relationships represented in the model both demonstrate the complexity of RL and help designing strategies for an integrated management of the reverse chain, according to legal and corporative requirements. We consider that the broader view on the stakeholders, their relationships and interdependence along the reverse logistics chain in Brazil, as shown in the model, could help the government foster reverse logistics initiatives. By providing fiscal incentives, tax exemption or compensation mechanisms, government policies could free the reverse logistics processes from the extra costs generated by cumulative taxes, thus generating new business opportunities. As discussed in this article, including waste pickers into RLS requires a coordinated effort that may benefit from the model's conjoint view on the players' activities

Financial incentives are also essential, because of the cultural and technological barriers also Financial incentives are also essential, because of the cultural and technological barriers also identified in our research. Brazilian managers still perceive RL as an extra cost imposed by legislation, and not as an opportunity to develop new business models. Also, the lack of technology and facilities in Brazil to recover the most valuable materials in electronic waste, which are shipped abroad, limits most of the potential revenues that could be generated locally by fully processing WEEE.

Another important point raised by our research is the need for shared solutions defined by the manufacturers themselves. The potential value generated in the reverse chain depends on large investments in technology and facilities to recover higher-value materials. This issue has not been deeply discussed in Brazil. The consortium initiatives to establish drop-off locations and recycling plants, whose costs should be shared by manufacturers, must be inves- 
tigated in future research as a way to increase the benefits of RL.

No previous research done in Brazil has considered WEEE deployment propositions, according to the stakeholder's opinion, through a qualitative analysis. In this context, future research should focus on two key elements for improving RL in developing countries. First, a tax exemption for recycling processes of low value-added electrical and electronic products may be economically viable, increasing interest and incentives. Secondly, the current tax structure does not offer any tax incentive or compensation to organizations dedicated to work with the recovery of post-consumer waste, thus ignoring the social and environmental benefits generated by this economic activity.

Finally, we argue that, in developing countries, RL legislation may be innovative not only in terms of economic and environmental gains, but also in increasing income and social inclusion. The Brazilian legislation is the first one in the world to include waste picker organizations as potential suppliers of RL services. But considering the environmental and health risks involved in the activity of separating and dismantling WEEE, and the low interest and distrust from manufacturers and recyclers in working in partnership with waste pickers, they are not expected to participate in the reverse logistics flow without proper financial and training support.

\section{REFERENCES}

ABINEE - Associação Brasileira da Indústria Eletro Eletrônica. $<\underline{\text { www.abinee.org.br }}>$ (retrieved 06.05.2012).

ABNT - Associação Brasileira de Normas Técnicas. ABNT CB-03:111 <http://www.abntonline.com.br $>$ (retrieved 09.11.2012).

ABNT NBR 16156:2013. Resíduos de Equipamentos Eletroeletrônicos. Requisitos para a Atividade de Manufatura Reversa. $<$ http://www.abntonline.com.br $>$ (retrieved 09.04.2013).

Almeida, C. M. V. B, Rodrigues, A. J. M., Bonilla, S. H., Giannetti, B. F. (2010). Emergy as a tool for Ecodesign: evaluating materials selection for beverage packages in Brazil. Journal of Cleaner Production, v. 18, i. 1, pp. 32-43

Araújo, M. G., Magrini, A., Mahler, C. F., Bilitewski, B. (2012). A model for estimation of potential generation of waste of electric and electronic equipment in Brazil. Waste Management, v. 32 , i. 2 , pp. $335-42$.

Atasu, A., Van Wassenhove, L. N. (2012). Operations Perspective on Product Take-Back Legislation for E-Waste: Practice, Trends and Research Needs. Production and Operations Management, v. 1 , i. 3 , pp. $407-422$
Augusto, E. E. F. (2014). Logística reversa de computadores e celulares: desafios e perspectivas para o modelo brasileiro. Dissertação de mestrados. Programa de Pós-graduação em administração. Centro Universitário da FEI. São Paulo. Brasil.

Bailey, K. D. (1994). Methods of social research. Fourth ed. The Free Press, New York.

Bardin, L. (2002). Análise de Conteúdo. São Paulo: Editora Edições.

Birch, A., Hon, K. K. B., Short, T. (2012). Structure and output mechanisms in Design for Environment (DfE) tools. Journal of Cleaner Production, v. 35, pp. 50-58.

Boukherroub, T., Ruiz, A., Guinet, A., Fondrevelle, J. (2014). An integrated approach for sustainable supply chain planning. Computers $\mathcal{E}$ Operations Research, In Press, Corrected Proof, Available online.

Braga Junior, S. S., Costa, P.R.; Merlo, E. M. (2006). Logística Reversa como alternativa de ganho para o varejo: um estudo de caso em um supermercado de médio porte. Simpósio de Administração da Produção, Logística e Operações Internacionais - SIMPOI, ninth ed. FGV, São Paulo.

Brazil. Presidência da República. Casa Civil (2010a). Política Nacional de Resíduos Sólidos - NPSW Lei 12.305 de 02 de agosto de 2010. <http://www.planalto.gov.br/ccivil 03/ Ato20072010/2010/Lei/L12305.htm> (retrieved 24.02.2011).

Brazil. Presidência da República, Casa Civil. (2010b). Política Nacional de Resíduos Sólidos - NPSW Decreto 7.404 de 23 de dezembro de 2010. <http://www.planalto.gov.br/ ccivil03/Ato2007-2010/2010/Decreto/D7404.htm> (retrieved 24.02.2011)

CNI - Confederação Nacional da Indústria. (2014). Proposta de implementação dos instrumentos econômicos previstos na lei $n^{\circ} 12.305 / 2010$ por meio de estímulos à cadeia de reciclagem e apoio aos setores produtivos obrigados à logística reversa. Brasília, 141 p.: il.

Corrêa, H. L., Xavier, L. H. (2013). Concepts, design and implementation of Reverse Logistics Systems for sustainable supply chains in Brazil. Journal of Operations and Supply Chain Management, v. 6, n. 1, pp. 1-25

Demajorovic, J., Huertas, M.K.Z., Boueres, J.A., Silva, A.G., Sotano, A.S. (2012). Logística reversa: como as empresas comunicam o descarte de baterias e celulares? Revista de Administração de Empresas, FGV, São Paulo, v. 52, n. 2, pp.

Demajorovic, J., Migliano, J. E. B. (2013). Política Nacional de resíduos Sólidos e suas implicações na cadeia da logística reversa de microcomputadores no Brasil. Gestão e Regionalidade, USCS, São Caetano do Sul, v. 29, n. 87, pp. 63-79.

Duarte, C. L., Mori, M. N., Oikama, H., (2009). Simultaneous Removal of Various Pesticides from Contaminated HDPE Packaging by Radiation Processing: Electron Beam and Gamma Radiation Comparison. Revista Brasileira de Ciências Ambientais. i. 12 , pp. 23-27

Fleischmann, M., Krikke, H. R., Dekker, R., Flapper, S. D. P. (2000). A characterization of logistics network for product recovery. The International Journal of Management Science, i 28, 
pp. 653-666.

Franco, R. G. F., Lange, L. C. (2011). Estimativa do fluxo dos resíduos de equipamentos elétricos e eletrônicos no município de Belo Horizonte, Minas Gerais, Brasil. Engenharia Sanitária e Ambiental, v.16, n.1, pp.73-82.

Godoi, C. K., Balsini, C. P. V. (2010). A pesquisa qualitativa nos estudos organizacionais brasileiros: uma análise bibliométrica. In: Godoi, C. K., Bandeira-de-Mello, R., Silva, A. B. Pesquisa qualitativa em estudos organizacionais: paradigmas, estratégias e métodos, second ed. Saraiva, São Paulo, c. 3, pp. 89-112.

Gomes, C. F. S., Nunes, K. R. A., Xavier, L. H., Cardoso, R., Valle, R. (2008). Multicriteria decision making applied to waste recycling in Brazil. Omega, v. 36, i. 3, pp. 395-404

González-García, S., Lozano, R. G., Buyo, P., Pascual, R. C., Gabarrell, X., Pons, J. R., Moreira, M. T., Feijoo, G. (2012). Eco-innovation of a wooden based modular social playground: application of LCA and DfE methodologies. Journal of Cleaner Production, v. 27, pp 21-31

Gottberg, A., Morris, J., Pollard, S., Mark-Herbert, C., Cook, M. (2006). Producer responsibility waste minimisation and the WEEE Directive: Case studies in eco-design from the European lighting sector. Science of The Total Environment, v. 359, n. $1-3$, pp. $38-56$

Govindan, K., Soleimani, H., Kannan, D. (2014). Reverse logistics and closed-loop supply chain: A comprehensive review to explore the future. European Journal of Operational Research, v. 240, n. 3, pp. 603-626

Gungor, A., Gupta, S. (1999). Issues in environmental conscious manufacturing and product recovery: a survey. Computers $\mathcal{E}$ Industrial Engineering, n. 36, pp. 811-853.

Hashemi, V., Mingyuan, C., Fang, L. (2014). Process planning for closed-loop aerospace manufacturing supply chain and environmental impact reduction. Computers $\mathcal{E}$ Industrial Engineering, v. 75, pp. 87-95

Henrique Júnior, S. S., Moura, F. P., Correa, R. S., Afonso, J. C., Vianna, C. A. (2013). In: Mantovano, J. L. Processamento de placas de circuito impresso de equipamentos eletroeletrônicos de pequeno porte. Química Nova, v.36, n.4, pp.570-576.

Jayaraman, V., Luo, Y. (2007). Creating competitive advantages through new value creation: a reverse logistics perspectives. Academy of Mangement Perspectives, v. 21, n. 2, pp. 56-73,

Jesus, F. S. M., Barbieri, J. C. (2013) Atuação de cooperativas de catadores de materiais recicláveis na logística reversa empresarial por meio de comercialização direta. Revista de gestão Social e Ambiental, v. 7, n. 3, out./dez, p. 20-36

Kaynak, R., Koçoglu, I., Akgün, A.E. (2014). The Role of Reverse Logistics in the Concept of Logistics Centers. Procedia - Social and Behavioral Sciences, v. 109, pp. $438-442$.

Kiddee, P., Naidu, R., Wong, M. H. (2013). Electronic waste management approach: an overview. Waste Management, v. 33, i. 5, pp. $1237-1250$.

Kokkinaki, A. I., Dekker, R., van Nunen, J., Pappis, C. (1999). An exploratory study on electronic commerce for reverse logistics. REVLOG Report EI-9950/A. Rotterdam: Erasmus Univer- sity, Econometric Institute.

Lambert, D. M., Cooper, M. C. (2000). Issues in supply chain management. Industrial Marketing Management, North-Holland, New York, n. 29, p. 65-83.

Lau. K. H., Wang, Y. (2009). Reverse logistics in the electronic industry of China: a case study. Supply Chain Management: An International Journal, v. 14, i. 6, pp. 447-465.

Leite, P. R., Lavez, N., Souza, V. M. (2009). Fatores da logística reversa que influem no reaproveitamento do lixo eletrônico: um estudo no setor da informática. In: XII Simpósio de Administração da Produção, Logística e Operações Internacionais SIMPOI. São Paulo, FGV

Li, J., Lopez, B., Liu, L., Zhao, N., Yu, K., Zheng, L. (2013). Regional or global WEEE recycling. Where to go? Waste Management, v. 33, i. 4, pp. 923-934.

Manomaivibool, P. (2009). Extended producer responsibility in a non-OECD context: The management of waste electrical and electronic equipment in India. Resources, Conservation and Recycling, v. 53, n. 3, pp 136-144

Manomaivibool, P., Vassanadumrongdee, S. (2011). Extended Producer responsibility in Thailand prospects for Policies on Waste Electrical and Electronic Equipment. Journal of Industrial Ecology. Vol. 15, No. 2, pp. 185-205

Mazon, M. T., Azevedo, A. M. M., Pereira, N. M., Silveira, M. A. (2012). Does Environmental Regulation Foster the Diffusion of Collaborative Innovations? A Study on Electronics Waste Regulation on Brazil. Procedia - Social and Behavioral Sciences, vol. 52, pp. 259-268.

McDonough, W., Braungart, M. (2002). Cradle to cradle: remaking the way we make things. North Point Press, New York.

McElhone, J. M. (1994). Logistics Management, in: Hampton, J.J. American Management Association - AMA Handboock, third edition, s. 10, pp. 31-33.

Milanez, B., Bührs, T. (2009). Extended producer responsibility. Journal of Cleaner Production, v. 17, n. 6, pp 608-615

MNCR, (2014). Movimento Nacional de Catadores de Materiais Recicláveis $<\underline{\text { www.mncr.org.br }}>$ (retrieved 16.02.2014).

Mureguesan, S., Laplante, P. A. (2011). IT for a greener planet. IT Professional, v. 3, n. 1. Sidney, IEEE.

Oliveira, C. R., Bernardes, A. M., Gerbase, A. E. (2012). Collection and recycling of electronic scrap: A worldwide overview and comparison with the Brazilian situation. Waste Management, vol. 32, Issue 8, pp. 1592-1610.

Petter, P. M. H., Veit, H. M., Bernardes, A. M. (2014). Evaluation of gold and silver leaching from printed circuit board of cellphones. Waste Management, v. 34, i. 2, pp. 475-482.

Ravi, V., Shankar, R., Tiwari, M. K. (2008). Selection of a reverse logistics project for end-of-life computers: ANP and goal programming approach. International Journal of Production Research, v. 26, i. 17, pp. 4849-4870.

Reveilleau, A. C. A. (2011). Política Nacional de Resíduos Sólidos: aspectos da responsabilidade dos geradores na cadeia 
do ciclo de vida do produto. Revista Internacional de Direito e Cidadania, n. 10, pp. 163-174 < www.reid.org.br/print/php/ CONT $=00000272 . h t m>($ retrieved 26.02.2012).

Ribeiro, H., Jabobi, P. R., Besen, G. R., Günther, W. M. R., Demajorovic, J., Viveiros, M. (2009). Coleta seletiva com inclusão social: cooperativismo e sustentabilidade. São Paulo: Annablume.

Rogers, D. S., Tibben-Lembke, R. S. (1998). Going backwards: reverse logistics trends and practices. Reverse Logistics Executive Council. Reno: University of Nevada.

Rogers, D. S., Tibben-Lembke, R. (2001). An examination of reverse logistics practices. Journal of Business Logistics. v. 22, i. 2, pp. $129-148$

Rotter, V.S., Chancerel P., Schill, Wolf-Peter. (2011). Practicalities of individual producer responsibility under the WEEE directive: experiences in Germany. Waste Management \& Research, v. 29 , i. 9 , pp. $931-944$

Sato, G. S., Carbone, G. T., Moori. R. G. (2006). Reverse logistics of agrochemical package in Brazil: Operational Practices. Revista de Gestão Integrada em Saúde do Trabalho e Meio Ambiente. São Paulo, InterfacEHS.

$\underline{\text { Schluep, M. Hagelueken, C., Kuehr, R., Magalini, F., Maurer, }}$ C., Meskers, C., Mueller, E., Wang, F., (2009). Recycling from e-waste to resources, Sustainable innovation and technology transfer. Industrial sector studies. United Nations Environment Programme.

Shane, F. Z. (2011) GREEN-IT: Why Developing Countries Should Care? International Journal of Computer Science Issues, v. 8 , n. 4 , p. $424-427$,

Shinzato, M. C., Hypolito, R. (2005). Solid waste from aluminum recycling process: characterization and reuse of its economically valuable constituents. Waste Management, v. 25, i. 1, pp. $37-46$

Silveira, G. T. R., Chang, S-Y. (2010). Cell phone recycling in the United States and potential recycling options in Brazil. Waste Management, i. 30, pp. 2278-2291.

Sodhi, M. S., Reimer, B. (2001). Models for Recycling Electronics End-Of-Life Products. Industrial and Manufacturing Engineering, v. 23, pp. 97-115.

Souza, M. T. S., Paula, M. B., Souza-Pinto, H. (2012), "O papel das cooperativas de reciclagem nos canais reversos pós-consumo", Revista de Administração de Empresas- RAE, São Paulo, Vol.. 52, No. 2, pp. 246-262.
Stock, J. R., Mulki, J. P. (2009). Product returns processing: an examination of practices of manufacturers, wholesalers, distributors and retailers. Journal of Business Logistics, v. 30, n. 1, pp. 33-62.

Thierry, M., Salomon, M., van Nunen, J., van Wassenhove, L. (1995). Strategic issues in product recovery management. California Management Review, v. 37, n. 2, pp. 114-135.

UMICORE. Electronic Scrap <http://www.preciousmetals.umicore.com/recyclables/eScrap/> (retrieved 22.02.2014).

Vermeulen, W. J. V., Kok, M. T. J. (2012). Government interventions in sustainable supply chain governance: Experience in Dutch front-running cases. Ecological Economics, v. 83, pp 183-196

Xiang, W., Ming, C. (2011). Implementing_Extended Producer Responsibility: vehicle remanufacturing in China. Journal of Cleaner Production, v. 19, n. 6-7, pp. 680-686

Yamane, L. H., Moraes, V. T., Espinosa, D. C. R., Tenório, J. A. S. (2011). Recycling of WEEE: characterization of spent printed circuit boards from mobile phones and computers. Waste Management, v. 31, i. 12 , pp. 2553-2558.

Wagner, T. P. (2009). Shared responsibility for managing electronic waste: A case study of Maine, USA. Waste Management. v. 29, i. 12, pp. 3014-3021.

Wang, F., Huisman, J., Meskers, C. E. M., Schluep , M., Stevels, A., Haglüken, C. (2012). The Best-of-2-Worlds philosophy: Developing local dismantling and global infrastructure network for sustainable e-waste treatment in emerging economies. Waste Management, Volume 32, Issue 11, pp. 2134-2146.

Widemer, R., Oswald-Krapf, H., Sinha-Khetriwalb, D., Schnellmannc, M., Heinz Bönia, H. (2005). Global perspectives on e-waste. Environmental Impact Assessment Review, v. 25 pp. 436-458.

Zanghelini, G. M., Cherubini, E., Orsi, P., Soares, S. R. (2014). Waste management Life Cycle Assessment: the case of a reciprocating air compressor in Brazil. Journal of Cleaner Production, v. 70, pp. 164-174.

Zeng, X., Zheng, L., Xie, H., Lu, B., Xia, K., Chao, K., Li, W., Yang, J., Lin, S., Li, J. (2012). Current Status and Future Perspective of Waste Printed Circuit Boards Recycling. Procedia - Environmental Sciences, v. 16, pp. 590-597. 


\section{AUTHOR'S BIOGRAPHY:}

João Ernesto Brasil Migliano: Mechanical and Production Engineer from FEI. Extensions in Finance and Marketing at USP and FGV. Specialist and Master (Stricto Sensu)in Business Administration with focus on Innovation and Sustainability from University Center of FEI. Professor of Ergonomics at FEI and FBRH, among of other institutions from 1975 up to 1991. Executive career at middle sized national and multinational companies.

Jacques Demajorovic: has a Bachelor degree in Economics, a master's degree in urban planning and is PhD in education. Since 1990 has been working in the field of environmental management and sustainability 90. From 2000 to 2009 worked as the coordinator of the following undergraduate courses: environmental management and Business administration and environmental management

Lucia Helana Xavier: Biology Undergraduate at Federal University of Rio de Janeiro (1997), MSc (2001) and Doctorate degree (2005) in Industrial Engineering at the Federal University of Rio de Janeiro. She has experience in Production Engineering with emphasis in Environmental Engineering, mainly in the following areas: Environmental management, Environmental performance (ISO 14031) and Reverse Logistics 